\title{
Physicochemical characterization of El Ouldja valley waters, in the province of Khenchela, eastern Algeria
}

\author{
Soumia Guilal ${ }^{1}\left[\right.$ [D $\cdot$ Abdelhak Darbouche ${ }^{1}$
}

Received: 22 March 2018 / Accepted: 4 September 2018 / Published online: 11 September 2018

(c) The Author(s) 2018

\begin{abstract}
This work has been carried out at the southern side of the Tabouant anticlinal in El Ouldja valley in the Aures, east of Algeria. The different water tables exploited belong to many lithological entities (evaporitic and carbonated). The combination of geology and statistics has allowed to study the chemistry origin of these waters. This is water of evaporitic and secondarily carbonates origin. The phenomena causing this class are numerous and are essentially linked to the aquifers chemical composition. The chemical analysis of all samples of the area confirms this. Waters salinity is very variable and generally high. Waters electrical conductivity ranges between 1504 and $6150 \mu \mathrm{S} \mathrm{cm}^{-1}$. The extreme chemical facies are chloride-sulfate and calcium-sulfate, with a predominance of this latter. Sulfate and chloride contents can locally reach the respective values of $1100 \mathrm{mg} / \mathrm{l}^{-1}$ and $650 \mathrm{mg} / \mathrm{l}^{-1}$. Thermodynamic analysis indicated the waters saturation with carbonates, calcite and dolomite, because of the degassing and the $\mathrm{CO}_{2}$ dissolution of evolutive formations, gypsum and halite. The crossed binary diagrams suggest that water salination might be attributed to water-rock interaction through the geochemical process of mineral dissolution, precipitation and ions exchange.
\end{abstract}

Keywords Chemical facies $\cdot$ Aquifer $\cdot$ Evaporites $\cdot$ Statistics $\cdot$ Precipitation

\section{Introduction}

Groundwaters and surface waters are resources used by humans for diverse purposes. The chemical composition of wells and springs waters is generally acquired during the migration of waters through the soil and their stay in the reservoir. Water in contact with the country rock acquires a mineral load typical of the crossed rocks. The elements in solution therein are informative of the aquifer.

El Ouldja valley is located southwest of the Khenchela province in the Aures, east of Algeria, and stretches over a surface area of $366 \mathrm{~km}^{2}$; it is part of the southern side of the Tabouant anticlinal. The valley forms a $U$ with a flat bottom and steep banks, and sometimes overhanging, it has a width of $860 \mathrm{~m}$ at elevation of 410 , characterized by a monoclinal structure with a slight dip toward the south-southwest and

Soumia Guilal

Soumia.guilal@hotmail.com

1 Faculty of Natural and Life Sciences, Department of Ecology and Environment, Laboratory Water, Environment and Renewable Energy, University of Abbes Laghrour, Khenchela, Algeria faults with a significant throw. The basin bedrock is mainly made up of blue-gray marls locally gypseous, alternating with more or less marl limestones and hard limestones of Upper Cretaceous age. These Upper Cretaceous deposits (Coniacian and Santonian C) of E-O direction have a southern dip ranging from $10^{\circ}$ to $20^{\circ}$. The valley is crossed by the El Arab wadi that runs from north to south often on its own alluvia and locally on the rocky substratum. In the basin, the present bed of the wadi has a width of about $100 \mathrm{~m}$. The wadi has two small tributaries on the right bank.

The basin is equipped with marl-limestone layers and limestone having a thickness varying from a centimeter to a meter, sometimes up to 2 or $3 \mathrm{~m}$. The thickness of the marl layers also varies from a centimeter to about $10 \mathrm{~m}$, sometimes even more.

El Ouldja locality is known for its brackish waters due to the effect of geological nature of the terrains and especially to the presence of gypsum giving strong sulfate and chloride contents. This study focuses on the physicochemical characterization of El Ouldja valley waters. 


\section{Materials and methods}

\section{Geographical location}

El Ouldja is located southwest of the Khenchela chief town in the Aures, east of Algeria (Fig. 1), and stretches over a surface area of $366 \mathrm{~km}^{2}$. It is limited to the north by El M'Sara, to the east by Kheirane, to the south by the Biskra province and to the west by the Batna province. El Ouldja has at the end of 2016 a population of 3480 inhabitants.

From climatic point of view, this is an arid climate zone. The annual rainfall recorded at the main stations of study area is marked by a temporal variability. It ranges between a mean of 144 and $170 \mathrm{~mm}$. A pluviometric deficit of $15 \%$ is observed; this induces a decrease in runoff depth of nearly $53 \%$ reflected by a decrease in inputs of $32 \%$. The annual mean value is of $20^{\circ} \mathrm{C}$.

The drainage system is temporary (temporary runoff) and little developed. The configuration of this system can be explained, on the one hand, by the scarcity of rainwaters and on the other hand by the topographical nature of the area. So, the study area is essentially crossed by El Arab wadi, which is the natural drain and the collector of the valley and which runs from north to south. The catchment surface area of El Ouldja basin is of $1333 \mathrm{~km}^{2}$; it is characterized by a thalweg length of the order of $113 \mathrm{~km}$ and an overall slope angle of $1.36 \%$.

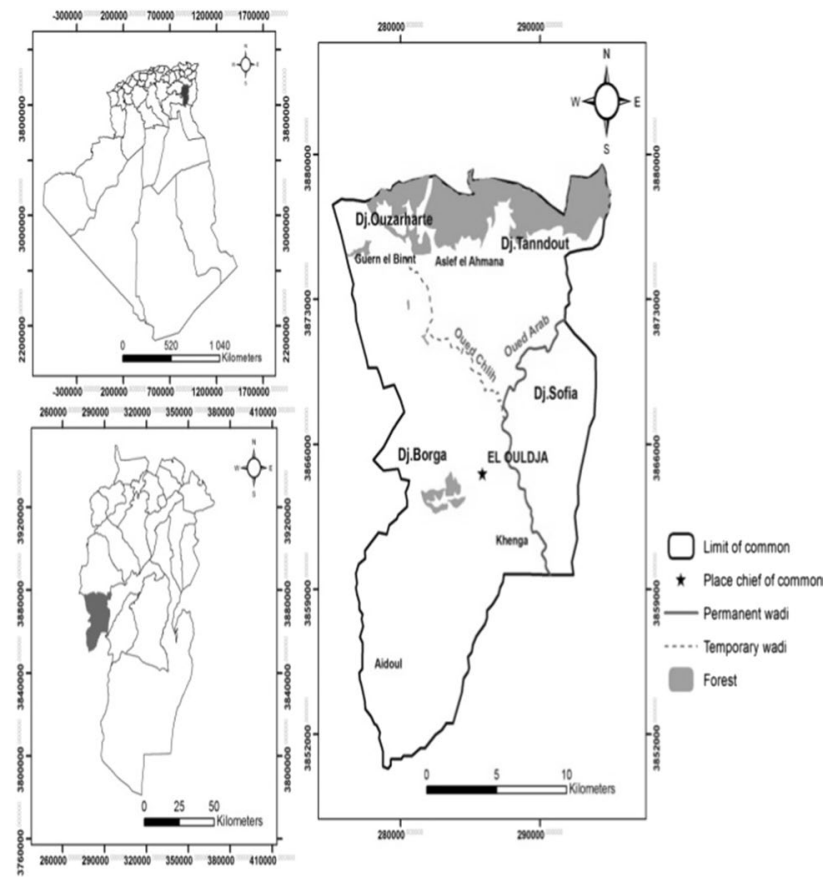

Fig. 1 Geographical location of study area
The study area is part of the southern side of the big anticlinal of Tabouant. The supporting soils outcropping in the basin are characterized by a monoclinal structure, with a slight dip southwest. The basin bedrock is mainly constituted of blue-gray marls locally gypseous, alternating with hard limestones of Upper Cretaceous age. These Upper Cretaceous deposits (Coniacian and Santonian C7) of E-O direction have a southern dip ranging from $10^{\circ}$ to $20^{\circ}$ (Fig. 2).

\section{Methods}

In order to better assess the physicochemical characteristics of El Ouldja valley waters, eleven (11) samples were taken from the study area in 2016, among which three samples from springs (S1, S2 and S3), three samples from El Arab wadi (upstream of wadi 1, at wadi 2 and downstream of wadi 3) and five samples from boreholes (water table) F1, F2, F3, F4, and F5 (Fig. 3).

The sampling campaign was performed during the period between November and December 2016. Chemical analyses were carried out at le Laboratoire de l'Agence Nationale des Ressources Hydriques (ANRH) of Khenchela.

Strict requirements were met during the whole period of sampling according to Rodier recommendations 2009. The samples were carried to the laboratory in a cool box and are then stored in a refrigerator until the analysis.

As regards the sensitive parameters such as temperature, electrical conductivity (EC) and $\mathrm{pH}$, they were measured

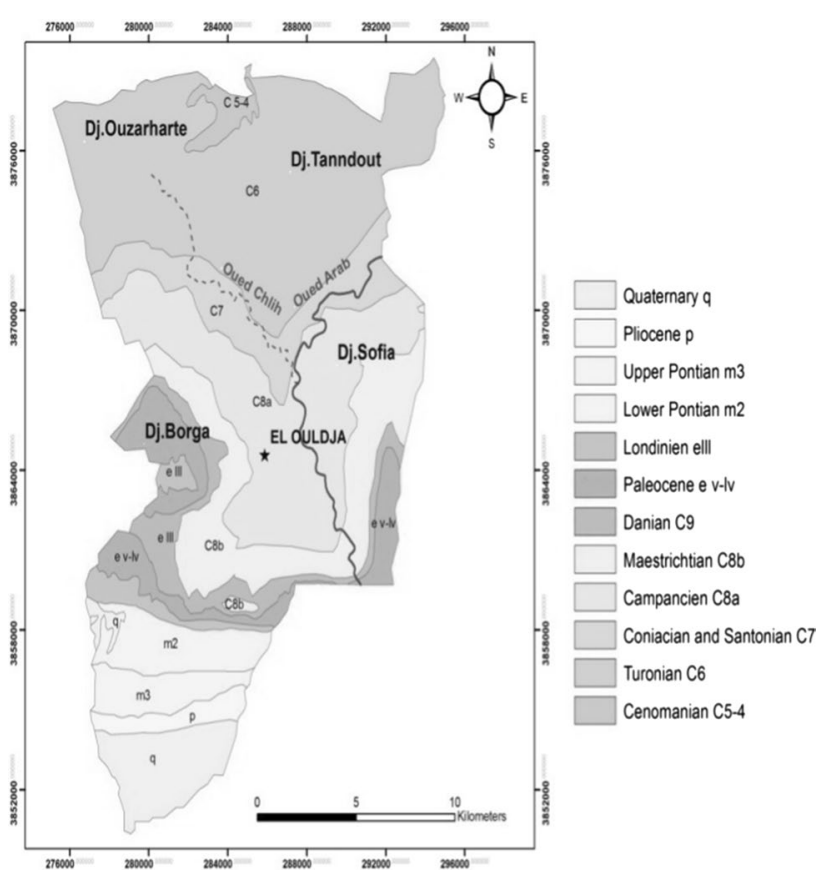

Fig. 2 Geological sitting of study area 


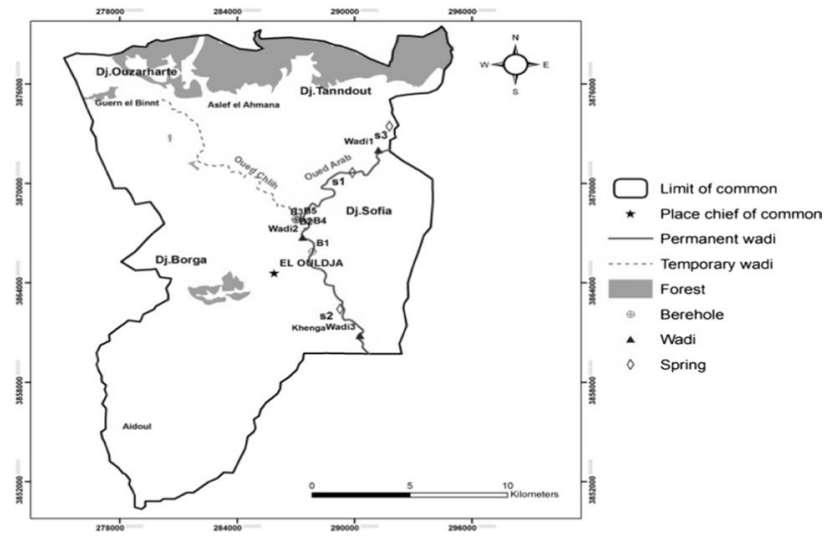

Fig. 3 Inventory map of study area

in situ using a multi-parameter probe. The chemical elements analyzed are calcium $\left(\mathrm{Ca}^{2+}\right)$, magnesium $\left(\mathrm{Mg}^{+2}\right)$, sodium $\left(\mathrm{Na}^{+}\right)$, potassium $\left(\mathrm{K}^{+}\right)$, chloride $\left(\mathrm{Cl}^{-}\right)$, bicarbonate $\left(\mathrm{HCO}_{3}{ }^{-}\right)$ and sulfate $\left(\mathrm{SO}_{4}^{-2}\right)$. Three methods of analysis have been used to determine the concentrations of different chemical elements. The determination of the content of bicarbonates and chlorides was done by titrimetry. The cations including the elements were determined using a PerkinElmer, 1100B flame atomic absorption and by titration potentiometric as proposed by Rodier et al. (1984). The results of the analyses are reported in Table 1.

We took the geological coordinates with a GPS type of Garming and measured four physical parameters in situ and seven major chemical elements, and we calculated four saturation index. The chemical facies is determined by software DIAGRAMME of the University of Avignon (France). Calculating the saturation index (SI) was effected, with the software PHREEQC (USGS).

\section{Results and discussion}

\section{Piezometry study}

The hydrodynamic study allowed us to characterize the flow and get a first grasp of the aquifers. This relationship has been further clarified in the hydrochemical study (El Moukhayar et al. 2015; Djoudi and Houha 2017).

The ANRH inventory allowed us to select 05 water points distributed over the study area in order to perform two piezometric campaigns during November 2016, and the two campaigns were undertaken, respectively, on 1 and 24 of November. These water points are located on the right and left banks of the wadi. According to the availability and the distribution of water points in the study area, a piezometric campaign was performed during the period November-December 2016, and the water table level was measured

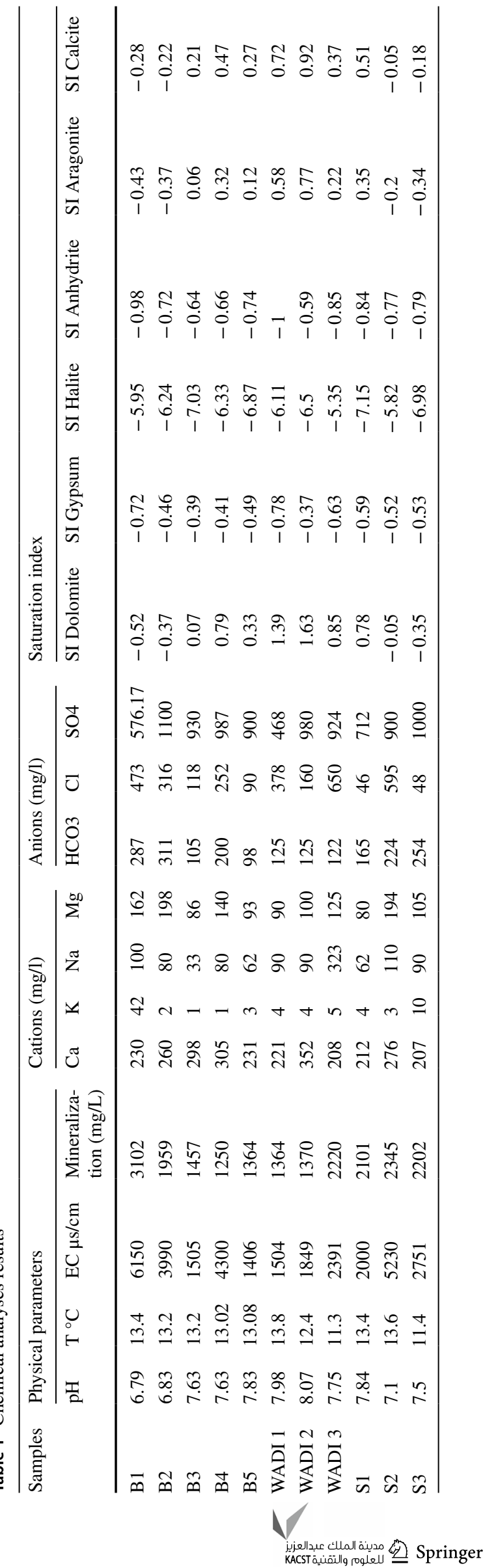


regularly (each month) at the boreholes $\mathrm{B} 1$ and $\mathrm{B} 2$ on the right bank, B3 and B4 at the bottom of the wadi and B5 on the left bank (Table 2).

Piezometric level $=$ Water point altitude(in $\mathrm{m})-$ Statical level(in $\mathrm{m})$

We observe that the water table level on the right bank (B1, B2) goes, respectively, from elevation 404.92 and 384.14 to 386.12 and 374.94 within about 2 weeks to dry up starting from November. The elevations at which these boreholes dry up lie almost at the limit of the rockhead.

On the left bank, the water table level (B5) goes from 399.75 to 386.25 within a week and then dries up. This sounding was not performed a long time enough in order to make sure that it was the water table that we measured and not the borehole water.

The boreholes (B3, B5) of the wadi bottom give a level near the level of waters in the wadi bed, with a slight fluctuation.

\section{Hydrogeochemistry}

The study of waters chemistry aims at identifying the waters chemical facies, their potability quality and their suitability for irrigation. It also allows to monitor the spatial evolution of physicochemical parameters and to assess their origin by correlating them with geology and piezometry (Khemmoudj and BendadoucheH 2016; Plummer 1991).

Table 2 Piezometric level variation of the water table

\begin{tabular}{llllll}
\hline Borehole & B1 & B2 & B3 & B4 & B5 \\
\hline Borehole level (m) & 426.12 & 394.44 & 336.32 & 336.40 & 415.55 \\
Water table level & 395.62 & 374.94 & 329.16 & 331.90 & 399.75 \\
$\quad \begin{array}{l}\text { 1/11/2016 } \\
\text { Water table level }\end{array}$ & sec & sec & 329.26 & 332.25 & $\mathrm{sec}$ \\
$\quad 24 / 11 / 2016$ & & & & & \\
\hline
\end{tabular}

The quasi-totality of the aquifer water points is intended to the supply of drinking water and to irrigation. The use of water should meet certain standards varying according to the type of use. For this purpose, a sampling concerning the different waters points (surface water and groundwater), regularly distributed over the whole study area, was performed during the campaign November-December 2016.

The data table shows that waters are characterized by low alkalinity (pH between 6.79 and 8, 07) and medium mineralization expressed by EC ranging from 1250 to $3120 \mu \mathrm{S} \mathrm{cm}^{-1}$. The physicochemical parameters analyses show high values of electrical conductivity (1504-6150 $\mu \mathrm{S} \mathrm{cm}^{-1}$ ).

The waters richness in $\mathrm{SO}_{4}^{-2}, \mathrm{Na}^{+}, \mathrm{Cl}^{-}$and $\mathrm{Ca}^{+2}$ elements is linked to the minerals dissolution that are likely to form by evaporation of salt-loaded waters and by evaporitic formations dissolution (Hsissou et al 1996). Conversely, $\mathrm{Ca}^{+2}$, $\mathrm{Mg}^{+2}$ and $\mathrm{HCO}_{3}^{-}$elements are linked to carbonates dissolution (Drever1997).

The contribution of correlation between the physicochemical parameters in groundwaters helps understand certain phenomena arising from water-rock interaction (Rodier et al 1984). This correlation allows to provide an approach about the common origin of certain parameters. We assume that a correlation is significant, if the correlation coefficient value $« r »$ is comprised between $[+0,5,1]$ (positive relation) and $[-0.5,-1]$ (negative relation) (Brinis et al. 2015). In our case, many links are significant, but at variable degrees (Table 3). The correlation matrix from this PCA indicates that the representative correlation coefficient $(0,80 \leq r \geq 0$, 99) highlights the links existing between these latter. These links show the elements evolving together, thereby indicating the same origin. These are especially the couples $\left(\mathrm{Mg}^{+2}\right.$ and $\mathrm{HCO}_{3}^{-}$). The conductivity is connected to elements such as $\mathrm{Mg}, \mathrm{K}+, \mathrm{Cl}-$ and $\mathrm{HCO}_{3}$, thereby confirming the evaporitic origin of these elements. Less significant values between elements, with values $(0,60<r<0,80)$, are developed between the elements such as $\mathrm{Na}-\mathrm{Cl}$, other elements are in an inversely proportional relation, and the correlation

Table 3 Correlation matrix between measured parameters

\begin{tabular}{|c|c|c|c|c|c|c|c|c|c|c|}
\hline Variables & $\mathrm{c} 25^{\circ} \mathrm{C}$ & $\mathrm{pH}$ & NO3 & $\mathrm{HCO} 3$ & $\mathrm{Cl}$ & $\mathrm{Ca}$ & $\mathrm{Mg}$ & $\mathrm{K}$ & $\mathrm{Na}$ & $\mathrm{SO} 4$ \\
\hline $\mathrm{c} 25^{\circ} \mathrm{C}$ & 1 & & & & & & & & & \\
\hline $\mathrm{pH}$ & -0.7878 & 1 & & & & & & & & \\
\hline NO3 & -0.2653 & 0.2914 & 1 & & & & & & & \\
\hline $\mathrm{HCO} 3$ & 0.8008 & -0.9126 & -0.1997 & 1 & & & & & & \\
\hline $\mathrm{Cl}$ & 0.5334 & -0.2744 & -0.3790 & 0.1953 & 1 & & & & & \\
\hline $\mathrm{Ca}$ & 0.0440 & 0.1979 & 0.5062 & -0.1363 & -0.1250 & 1 & & & & \\
\hline $\mathrm{Mg}$ & 0.8299 & -0.8630 & -0.2688 & 0.8540 & 0.5096 & 0.0121 & 1 & & & \\
\hline K & 0.5908 & -0.5211 & -0.1141 & 0.4747 & 0.2554 & -0.2750 & 0.2572 & 1 & & \\
\hline $\mathrm{Na}$ & 0.0541 & 0.0626 & -0.3970 & -0.1117 & 0.6943 & -0.3240 & 0.1442 & 0.0475 & 1 & \\
\hline SO4 & -0.0150 & -0.1691 & 0.0994 & 0.1392 & -0.1976 & 0.4215 & 0.3410 & -0.4843 & 0.0543 & 1 \\
\hline
\end{tabular}




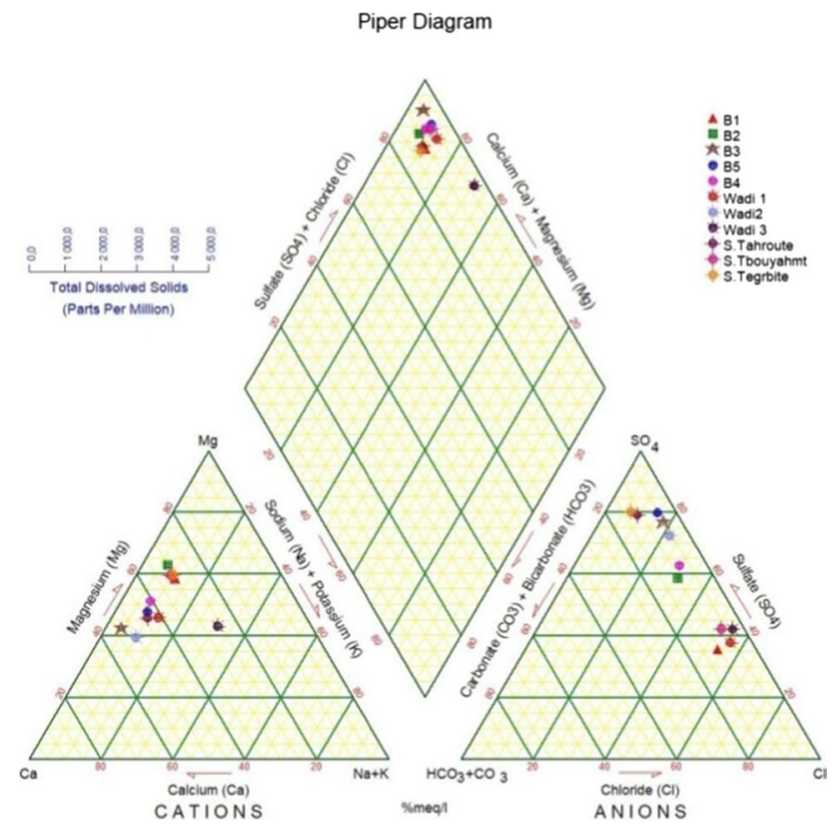

Fig. 4 Triangular piper diagram for the study area

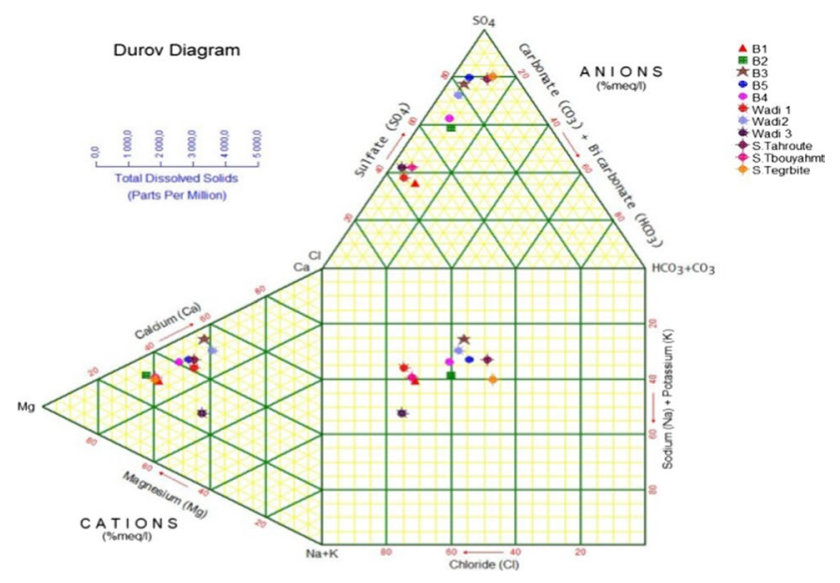

Fig. 5 Diagram of Durov representing the major element concentrations of El Ouldja valley

coefficient values of which are of the order $-0.8 \leq r \leq-0.9$ such as $\mathrm{Ph}-\mathrm{HCO}_{3}, \mathrm{Mg}-\mathrm{Ph}$; this is sometimes reflected by the base exchange between water alkalis versus soil alkaline-earths.

The results projection of chemical analyses on the analyses diagrams of chemical parameters reveals that PlioQuaternary groundwaters are marked by the abundance of $\left(\mathrm{SO}_{4}, \mathrm{Ca}^{+2}, \mathrm{Cl}^{-}, \mathrm{Mg}^{+2}, \mathrm{Na}^{+}\right)$ions. The plotting of analyses results of Plio-quaternary aquifer waters on the two diagrams (PIPER and DUROV) (Figs. 4, 5) reveals that El Ouldja valley waters are generally marked by sulfates that are sometimes accompanied by calcium, sometimes by magnesium and sometimes by chlorides, and this is directly connected to the presence of gypseous marls and to carbonate formations notably limestone and Albian dolomites.

\section{Salinity origin}

To better understand the groundwaters mineralization process, we have represented major elements according to chloride (Houha 2007) (Fig. 5). This latter is a conserved element, does not contribute to water-rock interaction, characterizes the waters salinity origin and constitutes a mixing tracer (El Achheb et al 2001). The disposition of different analyzed water points with respect to the mixing line of freshwater-saltwater (rainwater-seawater) can be of great importance for identifying other phenomena annexed to mixing processes. Groundwaters of different water points generally indicate an enrichment in $\mathrm{Ca}^{+2}$ and $\mathrm{SO}_{4}^{-2}$ and an impoverishment in $\mathrm{Na}^{+}$and $\mathrm{K}^{+}$, whereas for the $\mathrm{Mg}^{+}$, we have a points dispersion around the mixing line.

The major reactions recognized as responsible for the enrichment or the impoverishment of elements in groundwaters are the exchange of $\mathrm{Ca}^{+2}$ and $\mathrm{Mg}^{+2}$ due to carbonate water-rock interaction, base exchange between $\mathrm{Na}^{+}$ $-\mathrm{Ca}^{+2}-$ or $\mathrm{Na}^{+}-\mathrm{Mg}^{+2}$ and decrease or dissolution of sulfates (El Achheb et al 2001). In a carbonate environment, the simultaneous enrichment in $\mathrm{Ca}^{+2}$ and the impoverishment in $\mathrm{Mg}^{+2}$ are essentially explained by the water-rock interaction phenomenon as dolomitization, dissolution and precipitation (Selvakumar et al. 2017).

The exchange reaction of $\mathrm{Ca}^{+2}-\mathrm{Mg}^{+2}$ by dolomitization was reported as a main cause of ratio decrease $\mathrm{Mg} / \mathrm{Ca}$ in carbonate aquifers waters. This decrease is progressive according to increasing age of the aquifers terrains, controlled by the balance between calcite and dolomite, and is strongly dependent on temperature (Bouhlassa et al. 2008).

Sulfates reaction favors the carbonate minerals dissolution. This can further change the ratio $\mathrm{Mg} / \mathrm{Ca}$.

The base exchange feasibility of $\mathrm{Na}^{+}-\mathrm{Ca}^{+2}$ or $\mathrm{Na}^{+}-\mathrm{Mg}^{+2}$ was demonstrated on carbonate rocks by laboratory experiments (Al-Droubi et al 1980). These latter demonstrated that a low clay percentage in carbonate rocks could lead to significant changes in $\mathrm{Na}^{+}, \mathrm{Ca}^{+2}$ and $\mathrm{Mg}^{+2}$ concentrations in saltwater by base exchange. The between $\mathrm{Ca}^{+2}$ and $\mathrm{Cl}^{-}$ shows that the majority of water points are located below the mixing line (freshwater-saltwater). The enrichment in $\mathrm{Cl}$ observed can be due to anthropogenic activities.

The relation between $\mathrm{SO}_{4}^{-2}$ and $\mathrm{Cl}^{-}$shows that the majority of water points lie bellow the mixing line and that the ratio $\mathrm{SO}_{4} / \mathrm{Cl}$ is in favor of sulfates.

The enrichment of the points in sulfates is linked to the presence of evaporitic or saliferous formations on the limits and in the marl-gypsiferous substratum without forgetting

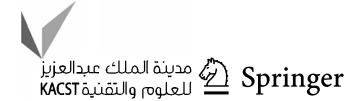


the contamination of agricultural origin (Tardy 1980; Hamed et al 2014; Tweed et al 2011).

The return of irrigation water containing fertilizers is an additional source of salinization of water bodies in the carbonate aquifer (Edmunds et al 2003; Trabelsi et al 2005).

In this area, the infiltration of irrigation and pluviometric waters loaded in salts and fertilizers (sulfates constitute one of the main components of fertilizers used in the area) is facilitated by the weak water table depth ( $2 \mathrm{~m}$ near EL Arab wadi, $15 \mathrm{~m}$ on the limits) and the good permeability of the aquifers terrains.

$\mathrm{Na}^{+}$deficit is explained by the ion base exchange phenomenon between water and the aquifer and is reflected by $\mathrm{Na}^{+}$adsorption and $\mathrm{Ca}^{+}$release (Hamed et al 2014; Demdoum and Djebbar 2009; Benaabidate 2000) These waters are principally controlled by cation exchange reactions between water and Pontian red clay reflected by a sodium fixation and calcium release. The relation between $\mathrm{K}^{+}$and $\mathrm{Cl}^{-}$shows an enrichment of nearly $50 \%$ of analyzed water samples with respect to the mixing line. This enrichment can be due to dolomite dissolution.

The relation between $\mathrm{K}^{+}$and $\mathrm{Cl}^{-}$shows that the majority of the points lie bellow the mixing line, except certain points approaching this line, thereby indicating that the most likely origin might be pollution (Hassad et al 2017; Kendouci et al 2016) (Fig. 6).

\section{Saturation index (SI)}

The water balance with the matrix is often expressed by the saturation index:

$\mathrm{SI}=\log (\mathrm{IAP} / \mathrm{Ks})$

where IAP is the product activity of the concerned ions and $\mathrm{Ks}$ is the product of solubility of the considered mineral (Bouhlassa et al. 2008) (Fig. 7).

The saturation degree, the undersaturation or the state of a solution balance toward a mineral is only appreciable if the solubility product can be compared to the product of the ionic activity of referential ions in the solution (Al-Droubi et al 1980). A null saturation index does not mean that water is in balance with the studied mineral. Water will be undersaturated if $\mathrm{SI}<0$ (mineral dissolution) and saturated if SI $<0$ (mineral precipitation) (Drever 1997). The significant results of all samples of analyzed waters (Fig. 8) indicate that these latter are saturated with respect to carbonate formation such as calcite, dolomite, and aragonite and are undersaturated with respect to evaporitic formations such as halite, gypsum and anhydrite. The minerals saturation index in water stresses that only carbonate minerals tend to precipitate notably under the form of dolomite. Unlike, evaporitic minerals are in dissolution, thereby allowing for evaporitic elements to appear in water at relatively high concentrations
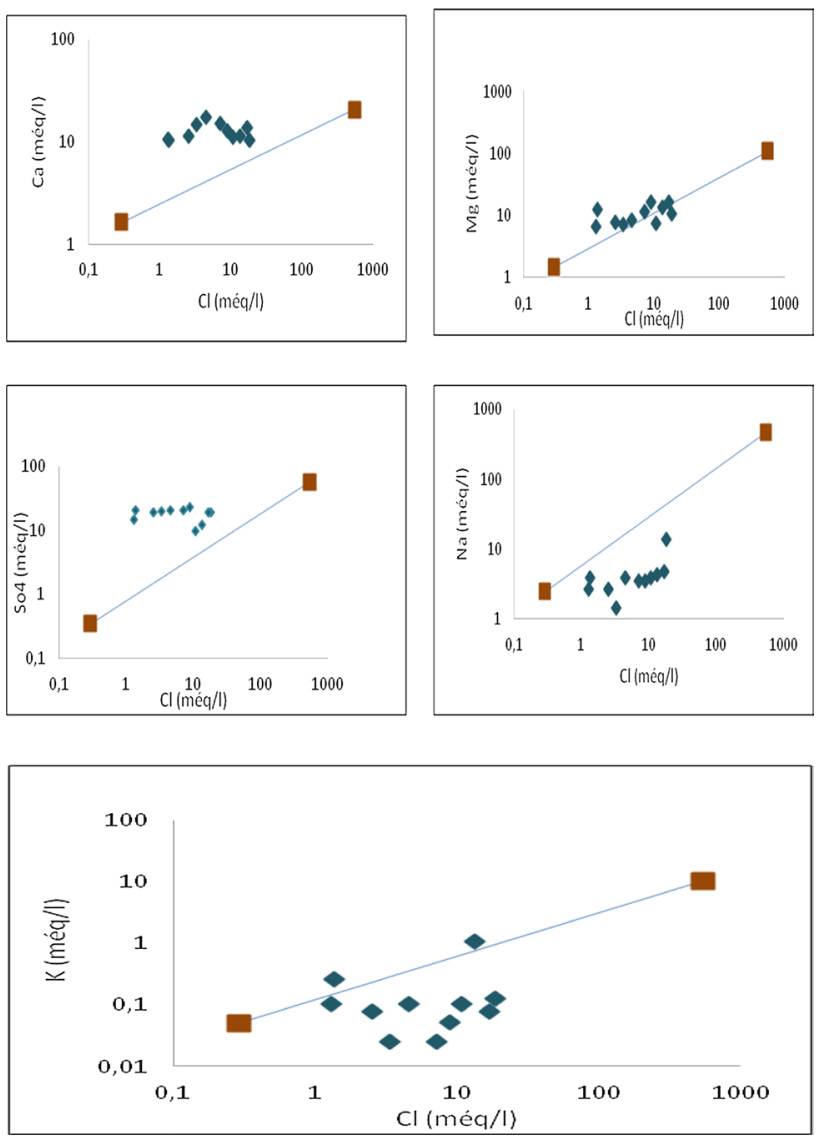

Fig. 6 Concentration variation of major elements according to chloride of El Ouldja valley springs waters

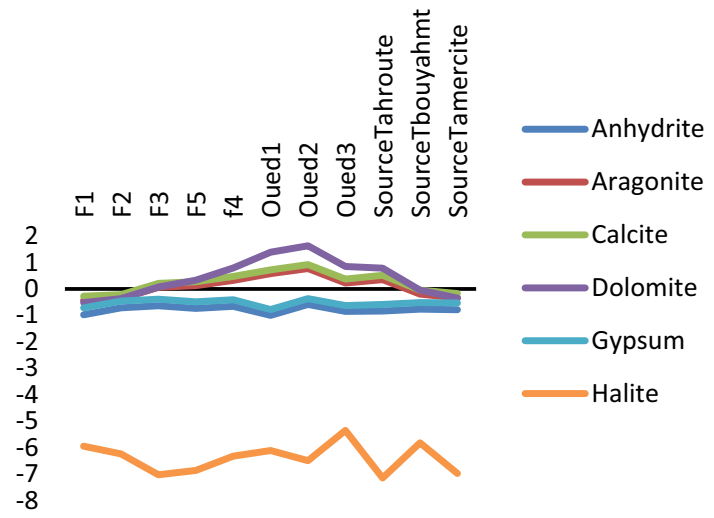

Fig. 7 Saturation index variation of minerals

and explain the predominance of calcium-sulfate facies by halite dissolution.

The projection variables on the conception of F1-F3 (Fig. 5) highlight two groups:

The axis $\mathrm{F} 1$ expresses $42.22 \%$ of variance; the positive part of this axis is linked to the variables group $\mathrm{Cl}, \mathrm{SO}_{4}, \mathrm{Mg}$, 


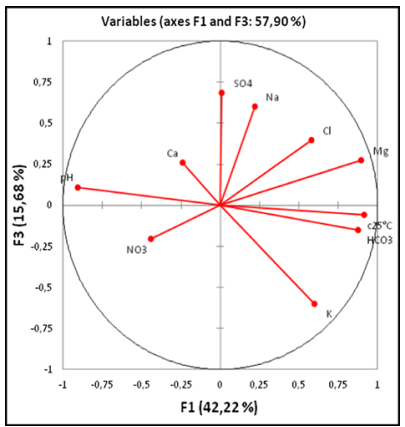

Fig. 8 Analysis within the variables

Table 4 Proper values of the first three axes CPA

\begin{tabular}{lrrr}
\hline Axis component & \multicolumn{1}{l}{ F1 } & \multicolumn{1}{l}{ F2 } & \multicolumn{1}{c}{ F3 } \\
\hline Eigen value & 4.2217 & 2.1329 & 1.5682 \\
Variability (\%) & 42.2171 & 21.3290 & 15.6822 \\
Cumulative (\%) & 42.2171 & 63.5461 & 79.2283 \\
\hline
\end{tabular}

$\mathrm{Na}, \mathrm{HCO}_{3}$ and $\mathrm{K}$ and to conductivity that generally explains waters evaporitic mineralization, with a deep water flow and a strong water-rock interaction. The axis F3 accounts for 15, $68 \%$ of the explained variance; it is determined by calcium and nitrate that reflect polluted waters (anthropogenic pollution) with the presence of the clay fraction (Table 4).

Figure 9 shows the three water types:

- F3. F4. F5. S1. wadi 2 calcium-sulfate.

- F2. S3 calcium-magnesium-sulfate.

- F1. S2 magnesium-chloride-sulfate.

- Wadi 1 calcium-chloride-sulfate.

- Wadi 3 sodium-chloride-sulfate.

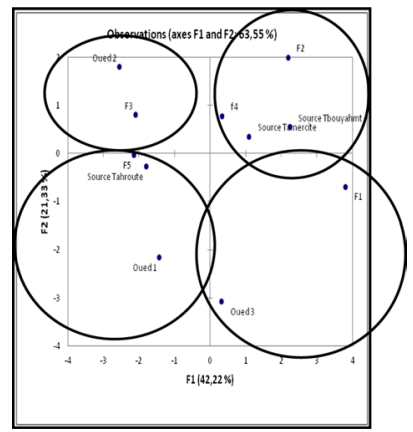

Fig. 9 Individual projection of water springs space (factorial design F1-F3)

\section{Conclusion}

Groundwaters exploited in the southern side of the Tabouant anticlinal in the El Ouldja valley are impacted both by minerals of evaporitic rocks and those of carbonate rocks. In fact, these two types of rocks make up the essential exploited aquifers in the area. The evaporitic group is dominant with $90 \%$ of analyzed samples, as a result of gypsum and halite dissolution. The carbonate waters group accounts only for $10 \%$ of samples owing to limestone dissolution. The statistical study by ACP highlights the links existing between the chemical parameters responsible for the mineralization and points out two poles, evaporitic and carbonated poles. The hydrochemical and thermodynamic study by means of PHREEQC leads to the same result and reveals the existence of two chemical groups: One is evaporitic, and the other is carbonated.

Open Access This article is distributed under the terms of the Creative Commons Attribution 4.0 International License (http://creativeco mmons.org/licenses/by/4.0/), which permits unrestricted use, distribution, and reproduction in any medium, provided you give appropriate credit to the original author(s) and the source, provide a link to the Creative Commons license, and indicate if changes were made.

\section{References}

Al-Droubi A, Fritz B, Gac JY, Tardy Y (1980) Generalized residual alkalinity concept; application to prediction of the chemical evolution of natural waters by evaporation. Am J Sci 280(6):560-572

Benaabidate L (2000) Caractérisation hydrologique du bassin versant de Sebou : hydrogéologie, qualité des eaux et géochimie des eaux thermales. PHD Thesis. Es-sc, F.S.T. Fès, 250

Bouhlassa S, Alechcheikh C, Kabiri L (2008) Origine de la minéralisation et de la détérioration de la qualité des eaux souterraines de la nappe phréatique du Quaternaire du bassin-versant de Rheris (Errachidia, Maroc). Science et changements planétaires/Sécheresse 19(1):67-75

Brinis N, Boudoukha A, Hamel AA (2015) Analyse statistique et géochimique de la dynamique des paramètres physico-chimiques des eaux souterraines du synclinal de ghassira Algérie orientale. LARHYSS J 22:123-137

Demdoum A, Djebbar M (2009) Caractérisation hydrochimique et rapport isotopique sur la salinité du bassin d'el eulma en région sud-sétifienne (algérie nord orientale). Sci Et Technol 30:19-26

Djoudi S, Houha B (2017) Hydrochemical characterization of the upper plains aquifers: case of the plain of F'kirina Ain-Beïda, Northeastern Algeria. Desalin Water Treat 21507(2017):1-8

Drever JF (1997) The geochemistry of natural waters, 3rd edn. Prentice-Hall INC, New York, p 379

Edmunds WM, Guendouz AH, Mamou A, Moula A, Shand P, Zouari K (2003) Groundwater evolution in the Continental Intercalaire aquifer of southern Algeria and Tunisia: trace element and isotopic indicators. Appl Geochem 18:805-822

El Achheb A, Mania J, Mudry J (2001) Processus de salinisation des eaux souterraines dans le bassin Sahel-Doukkala (Maroc occidental). In: First International Conference on Saltwater Intrusion

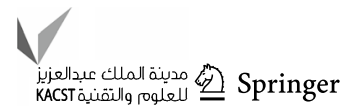


and Coastal aquifers-Monitoring, Modeling and Management, Essaouira, Morocco

El Moukhayar R, Bahir M, Carreira P (2015) Estimation of groundwater recharge in arid region through hydrochemistry and isotope case study Kourimat basin morocco. LARHYSS J 23(2015):1112-3680

Hamed Y, Ahmadi R, Demdoum A, Gargouri I, Bouri S, Ben Dhia H, Al-Gamal S, Laouar R, Choura A (2014) Use of geochemical, isotopic, and age tracer data to develop models of groundwater flow: a case study of Gafsa mining basin-Southern Tunisia. J Afr Earth Sci 100:418-436

Hassad S, Ouldjaoui M, Houha B (2017) Hydrogeochimical Characterization of Groundwater in the plateau of mellagou. Western Area of Khenchela, East of Algeria. Res J Pharm Biol Chem Sci ISSN 0975-8585 8(3)

Houha B (2007) Etude de fonctionnement hydrogéochimique, salin et isotopique des eaux de Khenchela. PHD Thesis, University Avignon, France, p 140

Hsissou Y, Chauve P, Mania J, Mangin A, Bakalowicz M, Gaiz A (1996) Caractérisation des eaux de l'aquifère turonien du bassin du Tadla (Maroc) par le rapport des concentrations molaires $\mathrm{Sr}^{2+}$, $\mathrm{Ca}^{2+}$. J Hydrol 183(3-4):445-451

Kendouci MA, Kharroubi B, Mebarki S, Bendida A (2016) Physicochemical quality of groundwater and pollution risk in arid areas: the case of Algerian Sahara. Arab J Geosci 9(2):146

Khemmoudj K, BendadoucheH Merabet S (2016) Water resources in semi arid and sustainable development, case Djemila Northeast Algerian region. LARHYSS J 1112-3680(26):249-258
Plummer LN, Prestemon EC, Parkhurst-Reston (1991) Va., USA, NET PATH-USGS water resource investigations. Rep 9:1-4078

Rodier J, Beuffr H, Bournaud M, Broutin J. P, Geoffray Ch, Kovacsik G, Laport J, Pattee E, Plissier M, Rodi L, Vial J (1984) L'analyse de l'eau, eaux naturelles, eaux résiduaires, eau de mer, 7e édition. Ed. Dunod

Selvakumar S, Ramkumar K, Chandrasekhar N, Magesh NS, Kaliraj S (2017) Groundwater quality and its suitability for drinking and irrigational use in the southern Tiruchirappalli district, Tamil Nadu, India. Appl Water Sci 7:411-420

Tardy YSARL, Elements édit, pp 109 (1980)

Trabelsi R, Zaïri M, Smida H, Ben Dhia H (2005) Salinization of coastal aquifers: case of the North Sfax Sahel aquifer, Tunisia. J Geosci 337:515-524

Tweed S, Leblanc M, Cartwright I, Guillaume FG, Leduc C (2011) Arid zone groundwater recharge and salinisation processes; an example from the Lake Eyre Basin, Australia. Hydrol Sci J 408(3-4):257-275

Publisher's Note Springer Nature remains neutral with regard to jurisdictional claims in published maps and institutional affiliations. 